\title{
Description of two novel species of the genus Kitasatospora Ōmura et al. 1982, Kitasatospora cineracea sp. nov. and Kitasatospora niigatensis sp. nov.
}

Research Center for Biological Function, The Kitasato Institute, 5-9-1, Shirokane, Minato-ku, Tokyo 108-8642, Japan

\author{
Koichi Tajima, Yōko Takahashi, Akio Seino, Yuzuru Iwai \\ and Satoshi Ōmura
}

\begin{abstract}
Author for correspondence: Satoshi Ōmura. Tel: +8133444 6161. Fax: +81334448360. e-mail: omura-s@kitasato.or.jp
\end{abstract}

\begin{abstract}
Five actinomycete strains, SK-3255', SK-3406' ${ }^{\top}$, SK-3412, SK-3421 and OM-5023, were isolated using a novobiocin-containing agar medium from soil samples. These strains produced long spore chains on aerial mycelium and contained LL- and meso-diaminopimelic acids (DAPs) in the cell wall. On the basis of morphological and chemotaxonomic characteristics and phylogenetic analysis, these five strains were classified into the genus Kitasatospora. DNA-DNA hybridization and comparison of physiological characteristics revealed that strains SK-3255 and SK-3406 ${ }^{\top}$ differed from known species. Strains SK-3406', SK-3412 and SK-3421 were regarded as the same species. Strain OM-5023 was identified as Kitasatospora griseola. Therefore, two novel species are proposed, Kitasatospora cineracea sp. nov. and Kitasatospora niigatensis sp. nov., with the type strains $K$. cineracea SK-3255 $\left(=\right.$ IFO $^{\top} 16452^{\top}=\mathrm{JCM}^{\mathrm{T}} 10915^{\top}=$ NRRL B-23134') and $K$. niigatensis SK-3406 ${ }^{\top}\left(=\right.$ IFO $^{\top} 16453^{\top}=$ JCM $^{\top} 10916^{\top}=$ NRRL B-24135').
\end{abstract}

Keywords: Kitasatospora cineracea sp. nov., Kitasatospora niigatensis sp. nov., soil bacteria, entire $16 \mathrm{~S}$ rDNA

\section{INTRODUCTION}

The actinomycete genus Kitasatospora was proposed by Ōmura et al. (1982). Kitasatospora strains contain both LL-diaminopimelic acid (DAP) and meso-DAP as diamino acids in the cell wall. Aerial spores on solid culture and submerged spores in liquid culture contain LL-DAP, while mycelium in both cultures mainly contains meso-DAP (Ōmura et al., 1981, 1982; Takahashi et al., 1984a). These properties are unique characteristics of Kitasatospora strains. Members of the genus Kitasatospora were transferred to the genus Streptomyces on the basis of rRNA-targeted oligonucleotide probes and phenotypic properties (Wellington et al., 1992). However, the genus Kitasatospora was later revived by phylogenetic study

Abbreviations: DAP, diaminopimelic acid; ISP, International Streptomyces Project.

The DDBJ accession numbers for the $16 \mathrm{~S}$ rDNA sequences of strains SK$3255^{\top}$, SK-3406', SK-3412, SK-3421 and OM-5023 are respectively AB022875-AB022879. based on 16S rDNA sequence data (Zhang et al., 1997).

The physiological regulation and mode of spore formation of Kitasatospora strains were investigated by Takahashi et al. $(1991,1996)$. These data showed that Kitasatospora strains were different from Streptomyces strains in their mode of submerged spore formation. While the submerged spores of Streptomyces griseus were produced abundantly by random fragmentation of the mycelium, those of Kitasatospora strains were newly produced at the tips of the mycelium and the chains were released from the mycelium to yield the submerged spores.

To date, nine species of the genus Kitasatospora have been recognized in accordance with the Bacteriological Code: Kitasatospora setae Ōmura et al. 1983, Kitasatospora phosalacinea Takahashi et al. 1985, Kitasatospora griseola Takahashi et al. 1985, Kitasatospora mediocidica Labeda 1988, Kitasatospora cystarginea Kusakabe and Isono 1992, Kitasatospora cochleata (Nakagaito et al. 1993) Zhang et al. 1997, 
Kitasatospora paracochleata (Nakagaito et al. 1993) Zhang et al. 1997, Kitasatospora azatica (Nakagaito et al. 1993) Zhang et al. 1997 and Kitasatospora cheerisanensis Chung et al. 1999 (Ōmura et al., 1982, 1985; Takahashi et al., 1984b; Labeda, 1988; Kusakabe \& Isono, 1988; Nakagaito et al., 1992a; Chung et al., 1999). Strains of the genus have been found to produce more than 10 new compounds, with a variety of biological activities and structures (Takahashi et al., 1999). Since Kitasatospora strains seem to be useful as a microbial source in screening for new bioactive compounds, we have tried selective isolation of Kitasatospora strains from soil samples. Based on the observation that Kitasatospora strains were resistant to novobiocin (Iwai \& Takahashi, 1992), we carried out the isolation of actinomycetes from soil samples using a novobiocin-containing agar medium. We isolated 174 novobiocin-resistant actinomycetes from 13 different soil samples. Five of them, strains SK-3255 ${ }^{\mathrm{T}}$, SK-3406 ${ }^{\mathrm{T}}$, SK-3412, SK-3421 and OM5023 , were identified as belonging to the genus Kitasatospora. The taxonomic characterization of these five actinomycete strains is presented here.

\section{METHODS}

Selective isolation of novobiocin-resistant strains. Actinomycete strains SK $-3255^{\mathrm{T}}$ and $\mathrm{OM}-5023$ were isolated from soil samples collected in Nishigahara, Kita-ku, Tokyo, Japan. Strains SK-3406 ${ }^{\mathrm{T}}$, SK-3412 and SK-3421 were isolated from soil samples collected in Niigata City, Japan. These strains were isolated by using a novobiocin-containing agar medium consisting of $1 \%$ potato starch, $1 \%$ glycerol, $0.2 \% \quad \mathrm{~K}_{2} \mathrm{HPO}_{4}, \quad 0 \cdot 2 \% \quad\left(\mathrm{NH}_{4}\right)_{2} \mathrm{SO}_{4}, 0.1 \% \quad \mathrm{MgSO}_{4} .7 \mathrm{H}_{2} \mathrm{O}$, $0 \cdot 1 \% \mathrm{NaCl}, 0 \cdot 2 \% \mathrm{CaCO}_{3}, 50 \mu \mathrm{g}$ novobiocin $\mathrm{ml}^{-1}$ and $1 \cdot 2 \%$ agar $(\mathrm{pH} \mathrm{7 \cdot 0)}$.

Micro-organisms. The following strains were used for comparative studies: $K$. setae KM- $6054^{\mathrm{T}}, K$. phosalacinea KA$338^{\mathrm{T}}$, K. griseola KM-9660 ${ }^{\mathrm{T}}$, K. cochleata IFO $14768^{\mathrm{T}}$, K. cystarginea IFO $14836^{\mathrm{T}}, K$. paracochleata IFO $14769^{\mathrm{T}}$ and Streptomyces kifunensis IFO $15206^{\mathrm{T}}$.

Morphological characteristics. Cultures grown on inorganic salts/starch agar for 2 weeks at $28{ }^{\circ} \mathrm{C}$ were observed with a scanning electron microscope (model S-430; Hitachi). Samples for scanning electron microscopy were prepared by fixing the agar block in osmium tetroxide vapour for $12 \mathrm{~h}$, dehydrating by critical-point drying and then sputter coating with palladium under vacuum. Cells grown in yeast extract/ dextrose medium with submerged cultures were observed using a light microscope (model VANOX-S; Olympus).

Cultural and physiological characteristics. The International Streptomyces Project (ISP) media recommended by Shirling \& Gottlieb (1966) were used to investigate cultural and physiological characteristics. Cultures were observed after incubation at $27^{\circ} \mathrm{C}$ for 2 weeks. Colours and hues were determined according to the Color Harmony Manual (Taylor et al., 1958). Utilization of carbon sources was tested by growth on carbon utilization medium (ISP 9) (Pridham \& Gottlieb, 1948) supplemented with $1 \%$ carbon sources at $27^{\circ} \mathrm{C}$ for 2 weeks. Temperature ranges for growth were determined on inorganic salts/starch agar (ISP 4) using a temperature gradient incubator (Toyo Kagaku Sangyo).

Chemotaxonomic characterization. Isomers of DAP in whole-cell hydrolysates were determined by using TLC 

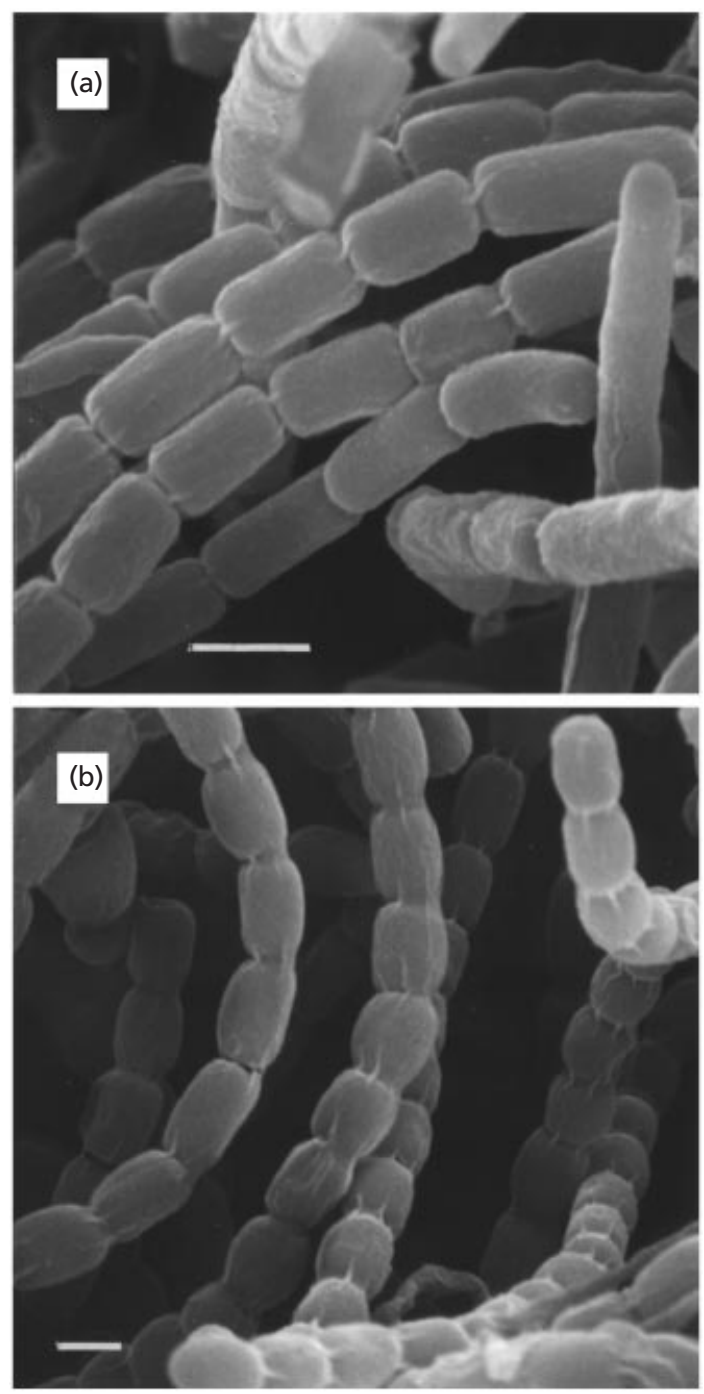

Fig. 1. Scanning electron micrographs of the spore chains of strains SK- $3255^{\top}$ (a) and SK-3406 ${ }^{\top}$ (b) grown on inorganic salts/starch agar for $14 \mathrm{~d}$ at $27^{\circ} \mathrm{C}$. Bars, $1 \mu \mathrm{m}$.

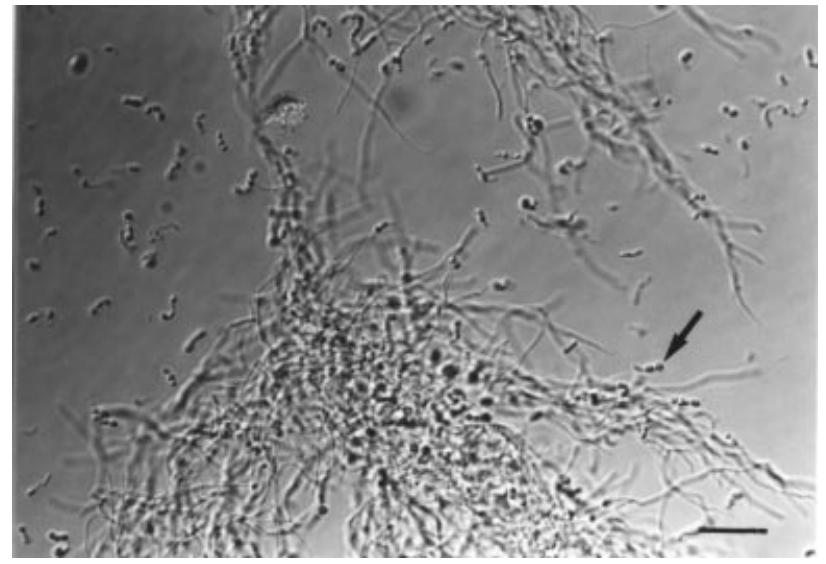

Fig. 2. Light micrograph of strain $\mathrm{SK}-3255^{\top}$ grown in yeast extract/dextrose medium for $2 \mathrm{~d}$ at $27^{\circ} \mathrm{C}$. The arrow shows a submerged spore. Bar, $10 \mu \mathrm{m}$. according to the methods of Becker et al. (1965) and Hasegawa et al. (1983). The $N$-acyl types of muramic acid were determined using the colorimetric method of Uchida \& Aida (1984). Whole-cell sugars were analysed by the method of Becker et al. (1965). Mycolic acids were detected by TLC according to Tomiyasu (1982). Menaquinones were extracted and purified according to Collins et al. (1977) and were analysed using HPLC equipped with a CAPCELL PAK C18 column (Shiseido) (Tamaoka et al., 1983). Phospholipids were extracted and identified following the method of Minnikin et al. (1977).

DNA base composition and DNA-DNA hybridization. Chromosomal DNA was prepared following the method of Marmur (1961). The $\mathrm{G}+\mathrm{C}$ content of DNA was determined by the HPLC method as described by Tamaoka \& Komagata (1984). DNA-DNA hybridization was carried out according to the method of Ezaki et al. (1989).

Analysis of 16S rDNA sequence. The 16S rDNAs were amplified by PCR with a PCR thermal cycler (TaKaRa) using three pairs of universal primers: $11 \mathrm{~F}$ (5' AGTTTGATCATGGCTCAG $\left.3^{\prime}\right)$ and 925R (5' CGTCAATTCATTTGAGTT 3'), 1115R (5' AGGGTTGCGCTCGTTG 3') and $685 \mathrm{~F}\left(5^{\prime}\right.$ GTAGCGGTGAAATGCGTA $\left.3^{\prime}\right)$ and $1510 \mathrm{R}$ (5' GGTTACCTTGTTACGACT 3') and 685F (5' GTAGCGGTGAAATGCGTA $3^{\prime}$ ). We also used two primer sets newly designed by the authors for the amplification and sequencing of the terminal regions of the 16S rRNA genes: 117R (5' CCCACGTGTTACTCACCC 3') and E-213F (5' AGCGTCCGTTCCTTGAGA 3'), located outside the 16S rRNA gene, for the 5'-terminal region, and SKS90R (5' TCAACGTTCCACCCATGAGC $3^{\prime}$ ), located within the $16 \mathrm{~S}-23 \mathrm{~S}$ rDNA internal transcribed spacer, and $1344 \mathrm{~F}\left(5^{\prime}\right.$ CTAGTAATCGCAGATCAGCA 3'), for the 3'-terminal region. The PCR was performed with the following protocol: initial denaturation at $94^{\circ} \mathrm{C}$ for 1 min followed by 30 cycles of denaturation at $94^{\circ} \mathrm{C}$ for $1 \mathrm{~min}$, annealing at $50^{\circ} \mathrm{C}$ for $1 \mathrm{~min}$ and extension at $72^{\circ} \mathrm{C}$ for $1.5 \mathrm{~min}$, with a final extension step at $72^{\circ} \mathrm{C}$ for $2 \mathrm{~min}$. The PCR products were purified by Prep-A-Gene (Bio-Rad) and were sequenced directly with an ABI model 373A automatic DNA sequencer and a PRISM Ready Reaction Dye Primer cycle sequencing kit (Applied Biosystems). Sequences of the other members of the genus Kitasatospora used for alignment and calculation of similarity levels were obtained from the DDBJ database. The sequences were checked manually and ambiguous positions were removed. CLUSTAL W (Thompson et al., 1994) was then used to generate evolutionary distances (the $K_{\text {nuc }}$ value of Kimura, 1980) and similarity values and to reconstruct the phylogenetic tree by the neighbour-joining method (Saitou \& Nei, 1987). The topology of the tree was evaluated by performing a bootstrap analysis (Felsenstein, 1985) using 1000 resamplings. The phylogenetic tree was drawn using the TREEVIEW software.

Nucleotide sequence accession numbers. The $16 \mathrm{~S}$ rDNA sequences of the five isolates, five known Kitasatospora species and Streptomyces kifunensis determined in this study were deposited in the DDBJ nucleotide sequence database; these accession numbers (with an $\mathrm{AB}$ prefix) are shown in Fig. 3.

\section{RESULTS}

\section{Morphological characteristics}

Fig. 1 shows scanning electron micrographs of aerial

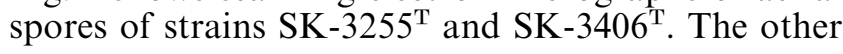


Table 2. Physiological characteristics that differentiate strains SK- $3255^{\top}$ and $\mathrm{SK}-3406^{\top}$ from related Kitasatospora species

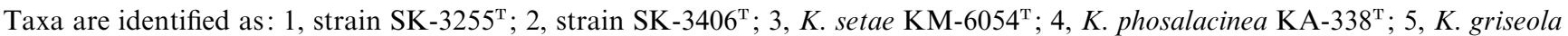
AM- $9660^{\mathrm{T}} ; 6, K$. cochleata IFO $14768^{\mathrm{T}} ; 7, K$. cystarginea IFO $14836^{\mathrm{T}} ; 8, K$. paracochleata IFO $14769^{\mathrm{T}}$. Data were taken from this

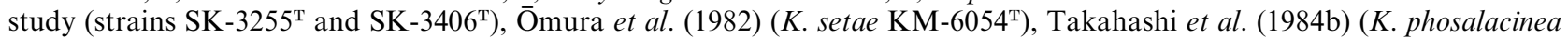
KA-338 and K. griseola AM-9660 ), Nakagaito et al. (1992a) (K. cochleata IFO $14768^{\mathrm{T}}$ and $K$. paracochleata IFO $14769^{\mathrm{T}}$ ) and Nakagaito et al. (1992b) (K. cystarginea IFO $\left.14836^{\mathrm{T}}\right)$. Characters are scored as: +, positive; -, negative; ND, not determined. All strains are positive for peptonization of milk, hydrolysis of starch and utilization of D-glucose. All strains are negative for liquefaction of gelatin and utilization of inositol and D-mannitol.

\begin{tabular}{|lcccccccc|}
\hline Characteristic & $\mathbf{1}$ & $\mathbf{2}$ & $\mathbf{3}$ & $\mathbf{4}$ & $\mathbf{5}$ & $\mathbf{6}$ & $\mathbf{7}$ & $\mathbf{8}$ \\
\hline Fermentation of melanoid pigment & - & - & - & - & - & + & - & + \\
Reduction of nitrate & - & + & - & + & - & - & - & + \\
Coagulation of milk & - & - & + & - & + & - & - & - \\
Utilization of: & & & & & & & & - \\
$\quad$ L-Arabinose & + & + & + & + & + & + & - & - \\
D-Xylose & + & + & + & + & + & - & - & - \\
Raffinose & + & - & - & + & + & - & - & ND \\
Melibiose & + & - & - & - & - & ND & ND & + \\
D-Fructose & - & - & - & + & - & - & - & - \\
D-Rhamnose & + & - & - & + & - & - & - & - \\
Sucrose & - & - & - & + & - & - & - & ND \\
Cellulose & - & - & - & - & - & ND & ND & $11-38$ \\
Temperature for growth $\left({ }^{\circ} \mathrm{C}\right)$ & $15-37$ & $15-41$ & $15-37$ & $15-42$ & $15-37$ & $13-38$ & $17-40$ & $72 \cdot 1$ \\
DNA G+C content $(\mathrm{mol} \%)$ & $73 \cdot 7$ & $73 \cdot 5$ & $73 \cdot 1$ & $73 \cdot 4$ & $73 \cdot 1$ & $72 \cdot 4$ & $70 \cdot 6$ & $73 \cdot 1$ \\
\hline
\end{tabular}

novel isolates formed similar spores. These strains produced aerial mycelia that consisted of long straight chains of 20 or more spores with smooth surfaces. No fragmentation of the vegetative mycelium, sporangium, zoospore or sclerotium was observed. Fig. 2 shows a light micrograph of strain $\mathrm{SK}-3255^{\mathrm{T}}$ in a submerged culture. The strain formed submerged spores in yeast extract/dextrose medium. The other four novel isolates also formed submerged spores (data not shown).

\section{Cultural and physiological characteristics}

Table 1 shows the cultural characteristics of the novel isolates. The five strains grew well on both synthetic and complex media. Table 2 shows physiological characteristics of strains SK-3255 $5^{\mathrm{T}}$ and SK-3406 ${ }^{\mathrm{T}}$. Strains SK-3412 and SK-3421 showed the same cultural characteristics and physiological properties as SK-3406 ${ }^{\mathrm{T}}$. The spore mass of strain SK $-3255^{\mathrm{T}}$ was oyster-white to silver-grey and no soluble pigment was produced. The strain utilized L-arabinose, D-xylose, raffinose, melibiose and D-rhamnose. The temperature range for growth was $15-37^{\circ} \mathrm{C}$. The spore mass of strain SK-3406 ${ }^{\mathrm{T}}$ was brownish white to brownish grey and no soluble pigment was produced. The strain utilized L-arabinose and $\mathrm{D}$-xylose. The temperature range for growth was $15-41^{\circ} \mathrm{C}$. The spore mass of strain OM-5023 was light grey to shadow-grey and yellowish soluble pigments were produced on oatmeal agar and glycerol/asparagine agar.

\section{Chemotaxonomy}

The five strains contained similar amounts of LL-DAP and meso-DAP in whole-cell hydrolysates of cells in submerged culture. Aerial spores on solid culture on inorganic salts/starch agar and submerged spores in liquid culture in yeast extract/dextrose medium contained LL-DAP. The vegetative mycelium and submerged mycelium mainly contained meso-DAP.

Galactose, mannose and ribose, but no arabinose or xylose, were detected in whole-cell hydrolysates. The diagnostic phospholipids phosphatidylethanolamine and phosphatidylinositol were detected, but phosphatidylcholine was not. This pattern corresponds to phospholipid type II (Lechevalier et al., 1977). MK$9\left(\mathrm{H}_{6}\right)$ and MK-9 $\left(\mathrm{H}_{8}\right)$ were detected as predominant menaquinones. The $N$-acyl type of muramic acid in peptidoglycan was the acetyl type. No mycolic acid was detected.

\section{S rDNA analysis}

Almost-complete 16S rDNA sequences were determined for the five novel isolates and for five previously described Kitasatospora species and Streptomyces kifunensis IFO $15206^{\mathrm{T}}$ using our newly designed primers. The lengths of the $16 \mathrm{~S}$ rDNA sequences of Kitasatospora strains ranged from 1515 to $1523 \mathrm{bp}$. The sequences of both the 5'- and 3'-terminal regions were conserved among the genus Kitasatospora strains. 


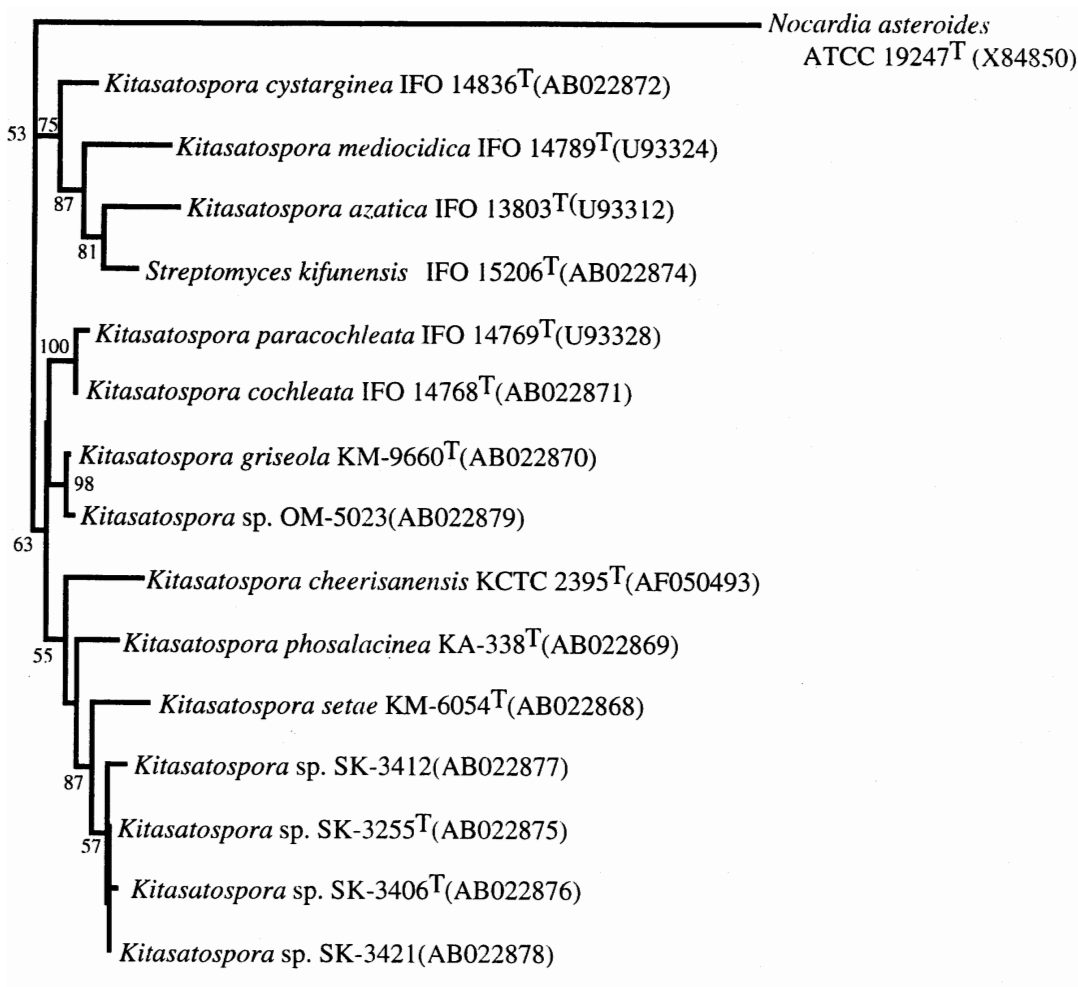

Fig. 3. A neighbour-joining dendrogram based on $1400 \mathrm{bp}$ of the $16 \mathrm{~S}$ rRNA gene sequences. The tree was validated by a bootstrap analysis (1000 replications) and values greater than $50 \%$ are indicated at the nodes. Bar, 0.01 substitutions per nucleotide position.

Table 3. DNA homologies among strains SK-3255', SK-3406 ${ }^{\top}$, SK-3412, SK-3421 and OM-5023 and related Kitasatospora species

\begin{tabular}{|c|c|c|c|c|c|}
\hline \multirow[t]{2}{*}{ Strain } & \multicolumn{5}{|c|}{ Source of photobiotin-labelled DNA: } \\
\hline & SK-3255 & SK-3406 ${ }^{T}$ & SK-3412 & SK-3421 & OM-5023 \\
\hline SK-3255 & 100 & & & & \\
\hline SK-3406 ${ }^{\mathrm{T}}$ & 37 & 100 & & & \\
\hline SK-3412 & 21 & 71 & 100 & & \\
\hline SK-3421 & 63 & 97 & 85 & 100 & \\
\hline OM-5023 & 23 & 48 & 47 & 37 & 100 \\
\hline K. setae $\mathrm{KM}-6054^{\mathrm{T}}$ & 53 & 35 & 50 & 44 & 54 \\
\hline K. phosalacinea KA-338 & 32 & 40 & 57 & 49 & 46 \\
\hline K. griseola AM-9660 ${ }^{\mathrm{T}}$ & 35 & 53 & 69 & 47 & 73 \\
\hline K. cochleata IFO $14768^{\mathrm{T}}$ & 15 & 3 & 15 & 7 & 31 \\
\hline K. cystarginea IFO $14836^{\mathrm{T}}$ & 26 & 10 & 29 & 12 & 36 \\
\hline K. paracochleata IFO $14769^{\mathrm{T}}$ & 42 & 12 & 22 & 8 & 22 \\
\hline
\end{tabular}

Fig. 3 shows a neighbour-joining tree generated from about $1400 \mathrm{bp}$, which is the length after removing gaps. The five novel isolates formed a clade with the members of the genus Kitasatospora. These strains showed high similarities, with values of $93.0-98.5 \%$, to the $16 \mathrm{~S}$ rDNA sequences of the previously described Kitasatospora species.

\section{DNA-DNA hybridization}

Table 3 shows the levels of DNA relatedness among the novel isolates and the other members of the genus Kitasatospora. DNA relatedness values between strain
SK $-3255^{\mathrm{T}}$ and the other Kitasatospora strains ranged from 15 to $63 \%$. The DNA relatedness values between strain SK-3406 ${ }^{\mathrm{T}}$ and strains SK-3412 and SK-3421 ranged from 71 to $97 \%$, but those between strain SK$3406^{\mathrm{T}}$ and the other strains were $3-48 \%$. The level of DNA relatedness between strain OM-5023 and $K$. griseola AM- $9660^{\mathrm{T}}$ was $73 \%$.

\section{DISCUSSION}

Based on the phenotypic, morphological and chemotaxonomic characteristics and genotypic data for the five novel isolates, it is concluded that they belong to 
the genus Kitasatospora. Nine Kitasatospora species have been described previously, but $K$. mediocidica, $K$. azatica and K. cheerisanensis were clearly distinguished from our strains by the production of soluble pigment, the morphology of the aerial mycelia and the fragmentation of the vegetative mycelia. Therefore, the five novel strains were compared with the related Kitasatospora species $K$. setae, $K$. phosalacinea, $K$. griseola, $K$. cochleata, $K$. paracochleata and $K$. cystarginea by phenotypic characteristics and DNADNA hybridization.

A comparison of the physiological properties of strains SK-3255 $5^{\mathrm{T}}$ and SK-3406 ${ }^{\mathrm{T}}$ and related Kitasatospora species is shown in Table 2. $K$. cochleata and $K$. paracochleata differ from strains SK-3255 ${ }^{\mathrm{T}}$ and SK$3406^{\mathrm{T}}$ in melanin formation and carbon source utilization. K. cystarginea differs from the two strains in carbon source utilization. $K$. phosalacinea utilizes Dfructose and sucrose, but the two novel strains do not. Only strain SK $-3255^{\mathrm{T}}$ utilizes melibiose. Strain SK$3255^{\mathrm{T}}$ differs from the previously described species in physiological characteristics and levels of DNA relatedness. Strains SK-3406 ${ }^{\mathrm{T}}$, SK-3412 and SK-3421 showed that they belong to the same species by their cultural and physiological characteristics and the level of DNA relatedness. They had high DNA-DNA reassociation values with each other, in the range $71-97 \%$, while they had low values with representative species. Strain SK-3406 ${ }^{\mathrm{T}}$ was similar to $K$. setae, but the DNA relatedness value was low. Strains SK $-3255^{\mathrm{T}}$ and SK-3406 ${ }^{\mathrm{T}}$ were clearly distinguished from previously described species. Strain OM-5023 is regarded as belonging to the species $K$. griseola by virtue of its cultural characteristics and the level of DNA relatedness. We therefore propose that strains SK$3255^{\mathrm{T}}$ and SK-3406 ${ }^{\mathrm{T}}$ should be described as new species of the genus Kitasatospora, Kitasatospora

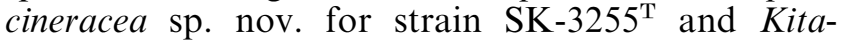
satospora niigatensis sp. nov. for strain SK-3406 ${ }^{\mathrm{T}}$.

As Streptomyces kifunensis formed a clade with the members of the genus Kitasatospora in phylogenetic analysis and had the phenotypic characteristics of the genus Kitasatospora, this micro-organism should be transferred to the genus Kitasatospora.

\section{Description of Kitasatospora cineracea sp. nov.}

Kitasatospora cineracea (ci.ne.ra'ce.a. L. fem. adj. cineraceus ash-grey, referring to the colour of the aerial mycelium).

A Gram-positive, aerobic, non-acid-fast actinomycete that produces yellowish brown vegetative mycelium and oyster-white to silver-grey aerial mycelium on yeast extract/malt extract agar, inorganic salts/starch agar, glycerol/asparagine agar and sucrose/nitrate agar. The spore chains are straight and flexuous, with 20 or more rod-shaped, smooth-surfaced spores $(0 \cdot 9$ $1.0 \times 0.6 \mu \mathrm{m})$ per chain. Submerged spores are formed in liquid culture. Soluble pigments, including melanin, are not produced. The cell wall contains both meso-
DAP and LL-DAP. Whole-cell hydrolysates contain galactose, mannose and ribose but lack arabinose and xylose. Phosphatidylethanolamine and phosphatidylinositol are contained in the polar lipid fraction. MK$9\left(\mathrm{H}_{6}\right)$ and MK-9 $\left(\mathrm{H}_{8}\right)$ are predominant menaquinones. The $N$-acyl type is the acetyl type. The strain is positive for peptonization of milk and hydrolysis of starch. DGlucose, L-arabinose, D-xylose, raffinose, melibiose and D-rhamnose are utilized for growth, but Dmannitol, D-fructose, inositol, sucrose and cellulose are not utilized. The temperature range for growth is $15-37{ }^{\circ} \mathrm{C}$. The strain is resistant to novobiocin at $100 \mu \mathrm{g} \mathrm{ml}{ }^{-1}$. The $\mathrm{G}+\mathrm{C}$ content of the DNA is $73.7 \mathrm{~mol} \%$.

The type strain is SK- $3255^{\mathrm{T}}\left(=\mathrm{IFO} 16452^{\mathrm{T}}=\mathrm{JCM}\right.$ $10915^{\mathrm{T}}=$ NRRL B-23134 ${ }^{\mathrm{T}}$ ).

\section{Description of Kitasatospora niigatensis sp. nov.}

Kitasatospora niigatensis (ni.i.gat.en'sis. N.L. fem. adj. niigatensis of Niigata, the city in Japan where the species originated).

A Gram-positive, aerobic, non-acid-fast actinomycete that produces ivory to brownish grey vegetative mycelium and brownish white to purplish grey aerial mycelium on yeast extract/malt extract agar, oatmeal agar, glycerol/asparagine agar and sucrose/nitrate agar. The spore chains are straight and flexuous, with 20 or more rod-shaped, smooth-surfaced spores $(1 \cdot 0$ $1 \cdot 1 \times 0 \cdot 5 \mu \mathrm{m})$ per chain. Submerged spores are formed in liquid culture. Soluble pigments, including melanin, are not produced. The cell wall contains both mesoDAP and LL-DAP. Whole-cell hydrolysates contain galactose, mannose and ribose, but lack arabinose and xylose. Phosphatidylethanolamine and phosphatidylinositol are contained in the polar lipid fraction. MK$9\left(\mathrm{H}_{6}\right)$ and MK- $9\left(\mathrm{H}_{8}\right)$ are predominant menaquinones. The $N$-acyl type is the acetyl type. The strain is positive for reduction of nitrate, peptonization of milk and hydrolysis of starch. D-Glucose, L-arabinose and Dxylose are utilized for growth, but raffinose, melibiose, D-mannitol, D-fructose, D-rhamnose, inositol, sucrose and cellulose are not utilized. The temperature range for growth is $15-41^{\circ} \mathrm{C}$. The strain is resistant to novobiocin at $100 \mu \mathrm{g} \mathrm{ml}^{-1}$. The $\mathrm{G}+\mathrm{C}$ content of the DNA is $73.5 \mathrm{~mol} \%$.

The type strain is SK $-3406^{\mathrm{T}}\left(=\mathrm{IFO} 16453^{\mathrm{T}}=\mathrm{JCM}\right.$ $10916^{\mathrm{T}}=\mathrm{NRRL}$ B-24135 $)$.

\section{ACKNOWLEDGEMENTS}

We thank Mayumi Shinose, Atsuko Matsumoto and $\mathrm{Xu}$ Ping for their help. Hideo Utsuno is gratefully acknowledged for revision of the English text. This study was supported by funds from the Japan Keirin Association.

\section{REFERENCES}

Becker, B., Lechevalier, M. P. \& Lechevalier, H. A. (1965). Chemical composition of cell-wall preparation from strains of various form-genera of aerobic actinomycetes. Appl Microbiol 13, 236-243. 
Chung, Y. R., Sung, K. C., Mo, H. K., Son, D. Y., Nam, J. S., Chun, J. \& Bae, K. S. (1999). Kitasatospora cheerisanensis sp. nov., a new species of the genus Kitasatospora that produces an antifungal agent. Int $J$ Syst Bacteriol 49, 753-758.

Collins, M. D., Pirouz, T., Goodfellow, M. \& Minnikin, D. E. (1977). Distribution of menaquinones in actinomycetes and corynebacteria. J Gen Microbiol 100, 221-230.

Ezaki, T., Hashimoto, Y. \& Yabuuchi, E. (1989). Fluorometric deoxyribonucleic acid-deoxyribonucleic acid hybridization in microdilution wells as an alternative to membrane filter hybridization in which radioisotopes are used to determine genetic relatedness among bacterial strains. Int J Syst Bacteriol 39, 224-229.

Felsenstein, J. (1985). Confidence limits on phylogenies: an approach using the bootstrap. Evolution 39, 783-791.

Hasegawa, T., Takizawa, M. \& Tanida, S. (1983). A rapid analysis for chemical grouping of aerobic actinomycetes. J Gen Appl Microbiol 29, 319-322.

Iwai, Y. \& Takahashi, Y. (1992). Selection of microbial sources of bioactive compounds. In The Search for Bioactive Compounds from Microorganisms, pp. 281-302. Edited by S. Ōmura. New York: Springer.

Kimura, M. (1980). A simple method for estimating evolutionary rates of base substitutions through comparative studies of nucleotide sequences. J Mol Evol 16, 111-120.

Kusakabe, H. \& Isono, K. (1988). Taxonomic studies on Kitasatosporia cystarginea sp. nov., which produces a new antifungal antibiotic cystargin. J Antibiot 41, 1758-1762.

Labeda, D. P. (1988). Kitasatosporia mediocidica sp. nov. Int $J$ Syst Bacteriol 38, 287-290.

Lechevalier, M. P., Bievre, C. D. \& Lechevalier, H. A. (1977). Chemotaxonomy of aerobic actinomycetes: phospholipid composition. Biochem Syst Ecol 5, 249-260.

Marmur, J. (1961). A procedure for the isolation of deoxyribonucleic acid from micro-organisms. J Mol Biol 3, 208-218.

Minnikin, D. E., Patel, P. V., Alshamaony, L. \& Goodfellow, M. (1977). Polar lipid composition in the classification of Nocardia and related bacteria. Int J Syst Bacteriol 27, 104-117.

Nakagaito, Y., Yokota, A. \& Hasegawa, T. (1992a). Three new species of the genus Streptomyces: Streptomyces cochleatus sp. nov., Streptomyces paracochleatus sp. nov., and Streptomyces azaticus sp. nov. J Gen Appl Microbiol 38, 105-120.

Nakagaito, Y., Shimazu, A., Yokota, A. \& Hasegawa, T. (1992b). Proposal of Streptomyces atroaurantiacus sp. nov. and Streptomyces kifunensis sp. nov. and transferring Kitasatosporia cystarginea Kusakabe and Isono to the genus Streptomyces as Streptomyces cystargineus comb. nov. J Gen Appl Microbiol 38, 627-633

Ōmura, S., Iwai, Y., Takahashi, Y., Kojima, K., Otoguro, K. \& Oiwa, R. (1981). Type of diaminopimelic acid different in aerial and vegetative mycelia of setamycin-producing actinomycete KM-6054. J Antibiot 34, 1633-1634.

Ōmura, S., Takahashi, Y., Iwai, Y. \& Tanaka, H. (1982). Kitasatosporia, a new genus of the order Actinomycetales. $J$ Antibiot 35, 1013-1019.
Ōmura, S., Takahashi, Y., Iwai, Y. \& Tanaka, H. (1985). Revised nomenclature of Kitasatosporia setalba. Int J Syst Bacteriol 35, 221.

Pridham, T. G. \& Gottlieb, D. (1948). The utilization of carbon compounds by some Actinomycetales as an aid for species determination. J Bacteriol 56, 107-114.

Saitou, N. \& Nei, M. (1987). The neighbor-joining method: a new method for reconstructing phylogenetic trees. Mol Biol Evol 4, 406-425.

Shirling, E. B. \& Gottlieb, D. (1966). Methods for characterization of Streptomyces species. Int J Syst Bacteriol 16, 313-340.

Takahashi, Y., Kuwana, T., Iwai, Y. \& Ōmura, S. (1984a). Some characteristics of aerial and submerged spores of Kitasatospora. J Gen Appl Microbiol 30, 223-229.

Takahashi, Y., Iwai, Y. \& Ōmura, S. (1984b). Two new species of the genus Kitasatosporia, Kitasatosporia phosalacinea sp. nov. and Kitasatosporia griseola sp. nov. J Gen Appl Microbiol 30, 377-387.

Takahashi, Y., Iwai, Y. \& Ōmura, S. (1991). Mode of submerged spore formation in Kitasatosporia setae. J Gen Appl Microbiol 37, 261-266.

Takahashi, Y., Iwai, Y. \& Ōmura, S. (1996). Physiological regulation of sporulation of Kitasatosporia setae in submerged culture. Actinomycetologica 10, 43-49.

Takahashi, Y., Seino, A., Iwai, Y. \& Ōmura, S. (1999). Taxonomic study and morphological differentiation of an actinomycete genus, Kitasatospora. Zentbl Bakteriol 289, 265-284.

Tamaoka, J. \& Komagata, K. (1984). Determination of DNA base composition by reversed-phase high-performance liquid chromatography. FEMS Microbiol Lett 25, 125-128.

Tamaoka, J., Katayama-Fujimura, Y. \& Kuraishi, H. (1983). Analysis of bacterial menaquinone mixtures by high performance liquid chromatography. J Appl Bacteriol 54, 31-36.

Taylor, H. D., Knoche, L. \& Granville, W. C. (editors) (1958). Color Harmony Manual, 4th edn. Chicago: Container Corporation of America.

Thompson, J. D., Higgins, D. G. \& Gibson, T. J. (1994). CLUSTAL W: improving the sensitivity of progressive multiple sequence alignment through sequence weighting, position-specific gap penalties and weight matrix choice. Nucleic Acids Res 22, 4673-4680.

Tomiyasu, I. (1982). Mycolic acid composition and thermally adaptative changes in Nocardia asteroides. J Bacteriol 151, 828-837.

Uchida, K. \& Aida, K. (1984). An improved method for the glycolate test for simple identification of acyl type of bacterial cell walls. J Gen App Microbiol 30, 131-134.

Wellington, E. M. H., Stackebrandt, E., Sanders, D., Wolstrup, J. \& Jorgensen, N. O. G. (1992). Taxonomic status of Kitasatosporia, and proposed unification with Streptomyces on the basis of phenotypic and 16S rRNA analysis and emendation of Streptomyces Waksman and Henrici 1943, 339 ${ }^{\mathrm{AL}}$. Int J Syst Bacteriol 42, 156-160.

Zhang, Z., Wang, Y. \& Ruan, J. (1997). A proposal to revive the genus Kitasatospora (Omura, Takahashi, Iwai, and Tanaka 1982). Int J Syst Bacteriol 47, 1048-1054. 